\title{
A Conversation with Dieter Grimm
}

\author{
Alec Stone Sweet ${ }^{1, *}$ and Giacinto della Cananea ${ }^{2}$ \\ ${ }^{1}$ Professor, Chair of Comparative and International Law, Faculty of Law, Hong Kong University, Hong Kong and ${ }^{2}$ Professor, \\ Department of Law, Bocconi University, Milan, Italy \\ *Corresponding author: asweet@hku.hk
}

(Received 24 November 2021; accepted 24 November 2021)

Keywords: Constitutional courts; Fundamental rights; International law; Judges; Constitutions

\section{A. Training and Academia}

D. Grimm: There were no academics in my family; I was the first to attend university. At age 18, I was determined to go into politics, and I thought law was the best preparation for a political career. My interest in politics remained, but the idea of becoming a politician faded away. I developed a genuine interest in the law, which I have always combined with political science. I started my studies at the University of Frankfurt am Main at a time when it was common for German students to change universities as one went along, an old tradition that hardly exists any more. From Frankfurt, I went to Freiburg, and then had a semester in Berlin, before returning to Frankfurt for the final exam. I had some impressive professors, but it would be difficult for me to identify a person as my mentor, or "teacher" in the traditional German sense.

After I got my law degree, I went to Paris for a year. But law teaching in Paris was even more anonymous than in Germany. The classes were large, and professors taught in robes. Students had no personal contact with faculty, and asking questions in class was unusual. I learned what good teaching meant at the Harvard Law School, where I earned an LL.M. degree in 1965. The best teacher I've ever had was Albert Sachs [1920-1991, former Dean of the Harvard Law School], who taught constitutional law and legal process. I also learned a great deal from Paul Freund [1908-1992] in constitutional law, and John Philip Dawson [1902-1985] in comparative law. The courses at Harvard answered a number of questions that intrigued me in German law schools, for which I had not gotten an answer.

Legal education in Germany then was mostly doctrinal. What is the correct interpretation of a legal norm? Is this a correct solution to a legal problem? Of course, there were also classes in legal philosophy, legal history. But these were disconnected from doctrine, and doctrine ("Dogmatik" in German) was what counted. My interest went beyond Dogmatik. Why is the law as it is? What effect does it have in practice? I did not deny the important of doctrine. Germany is a civil law system, and one cannot teach civil law completely in a common law mode. But one can-and should—contextualize the doctrinal approach. Harvard teaching combined theory and practice; functional questions played a bigger role than doctrinal ones. I knew that, if I were ever to become a professor, I would teach in this way, in a more contextualized way than was taught in Germany. 
Question: Usually, we think that that the best strategy for an academically-inclined German student is to attach themselves to an important professor, become part of his "Chair." The idea of the Doktorvater remains powerful.

D. Grimm: I had to go through the German process, attaching myself to someone, but I wanted to go abroad immediately. I asked myself: who is the most internationally well-known professor of the Frankfurt Law Faculty, someone who could help me receive scholarship funds? My parents would have been unable to support me. I chose a professor named Helmut Coing [1912-2000], a very important figure. His main field was late-Roman law and, in civil law, his main field was inheritance. But he also taught legal philosophy, which I made my second field, after public law. I got the scholarship and went to Paris. Returning from France, I started my training in legal practice, which is obligatory in Germany, and which I interrupted for Harvard.

When Harvard ended and the practical training was completed, Coing offered me a position at the Max Planck Institute for European Legal History, which had just been founded [1964]. Coing had the idea that there would be, sooner or later, a common European civil law, because one could not have a common market without it. One purpose of the Institute was to lay the foundations of this new updated, European jus commune. Of course, I made it clear to him that my main interest was public law. So we agreed that I would study the influence of written constitutions in the $19^{\text {th }}$ century on private law, which later became my Habilitation thesis.

I stayed at the Institute for more than 10 years, which was altogether too long in hindsight. I finished my Habilitation thesis when I was over 40. But I was offered a chair at the University of Bielefeld immediately after the Habilitation; and I had accumulated a lot of knowledge that I would not have learned had I spent that time as a professor.

Question: In Europe, the distinction between public law and private law, as separate domains, is quite rooted, although that distinction had broken down elsewhere.

D. Grimm: The dividing line between private law and public law was strict. If there were writings on this subject they concerned the differences, not the links between the two. This came much later; and I think I was one of the first Germans to explore the relationship. The famous Lüth decision of the Federal Constitutional Court [Bundesverfassungsgericht, BVerfG], ${ }^{1}$ which developed the horizontal effect of fundamental rights, made my work in legal history relevant for the actual law.

I started my constitutional law classes always by telling students that they could study criminal law without knowing anything about copyright law; they could study copyright law without knowing anything about taxation; and they could study taxation without knowing much about municipal law. But they could not study any of these subjects without knowing constitutional law. So, from the very beginning, I stressed that constitutional law was foundational of all law. And in my teaching, I always emphasized the ideas behind constitutions, and the social and political reality to which they applied.

Question: You must have seemed strangely cosmopolitan compared to most of your colleagues. You went to France and the United States. Then you insisted on teaching multiple branches of law from eclectic perspectives. This capacity to think across borders was not very common in the legal academy in Germany. Did it create tensions between you and your colleagues within the law school? How did you manage?

D. Grimm: What I did was risky. Some people thought: "oh, maybe he's a good legal historian but not much of a doctrinalist." Others said: "well, he's more of a political scientist than a lawyer." I was lucky that my first professorship was at the University of Bielefeld. Bielefeld was then a new university, with a reformist agenda and an inter-disciplinary orientation. I doubt that at more traditional faculties, say Munich or Bonn, I would even have made the short list for an interview. Bielefeld had a center for interdisciplinary studies, and there were highly esteemed and open-minded colleagues in neighboring disciplines. In sociology there was Niklas Luhmann [1927-1988]; and I had read a lot of Luhmann well before I got to know him personally.

${ }^{1}$ Bundesverfassungsgericht (BVerfG) (Federal Constitutional Court) BVERFGE 7, 158, 1 BvR 400/51, (Lüth, Jan.15, 1958). 
In political science, there was Claus Offe [born 1940], and the history faculty was the best in Germany, with Reinhart Koselleck [1923-2006], Hans-Ulrich Wehler [1931-2014], and Jürgen Kocka [born 1941]. At Bielefeld, I had as close relations with colleagues outside of the law faculty as within it. I was appointed to the Court while still a professor at Bielefeld.

Question: Looking backwards from the standpoint of a former constitutional judge, how would you assess German public law teaching and particularly constitutional law teaching today? Are you in favor of teaching more in English, and through cases?

D. Grimm: Teaching has improved, compared to my student days. The faculties are bigger now. When I was a student, each university had three professors in public law: In international law, constitutional law, and administrative law. Now we have twelve public law professors in Berlin alone. Many have studied abroad, particularly in the United States and the United Kingdom. The differences between Germany, and continental Europe in general, and the U.S. still exist, but they are shrinking. We continue to cultivate the German "systematic approach," but cases play an ever bigger role, especially in constitutional law with its thin textual basis, but also in private law with a Civil Code that dates from the 1880s. When I moved to Humboldt University, after leaving the Court, I adopted American teaching methods for my seminars in comparative constitutional law. In Germany, I taught in German, although much of the reading material was in English.

Question: How do you see the status of "comparative constitutional law" as a subject matter in Germany?

D. Grimm: I started it at Humboldt when I began there in 2000. Susanne Baer [Humboldt Law Faculty, now Justice on the BVerfG, born 1964], Christoph Möllers [Humboldt Law Faculty, born 1969] and many others now also teach comparative constitutional law, but in general there is still much less comparative public law than there should be. We also do not take into account sufficiently how inter-connected domestic, European, and international law really are.

Question: How important was European law in your teaching before you joined the Constitutional Court?

D. Grimm: As a student, I did not hear a word about European law. The European Economic Community was formed about the time I started my studies in law in 1957. It was not really taught outside of international law. But when I became a professor in 1979, the office next to mine belonged to Jochen Frowein [born 1934]. Frowein was a professor of public international law, and the German member of the European Commission of Human Rights, in Strasbourg. So, we had, of course, many conversations about European law. But I thought it had no importance for my work. The situation has dramatically changed since, of course. I doubt that you would find anyone on the Humboldt faculty today who does not teach German law along with the relevant European law. I blame myself for not having appreciated European law earlier. My wake-up moment was the Maastricht Treaty [1992] which reinforced the "ever closer Union" envisaged by the Treaty of Rome. But my story was more or less true for the whole field.

Question: The European Convention of Human Rights intersects directly with your interest in fundamental rights. Did you teach judgements of the Strasbourg Court, or take notice of its expanding influence?

D. Grimm: Not at that time. I knew some of the judgments, but it was extremely rare for the BVerfG to be found in violation of the Convention. Germany has a very high standard of fundamental rights protection, so we all had the impression that the Convention was a wonderful thing-but more for others than for us. The notion that it would play an important role in German rights protection became apparent only much later.

\section{B. Member of the German Federal Constitutional Court}

Question: Before turning to your experiences on the German Federal Constitutional Court, we have a more general question, which lies at the intersection of law, political science, and 
philosophy. Is rights adjudication a species of applied moral reasoning? That is, is the jurisprudence of fundamental rights a type of judicialized moral philosophy, and thus of politics?

D. Grimm: When you first sent me a list of questions, this was the one about which I thought for the longest time. Of course, fundamental rights provisions are legal expressions of values and moral judgements, and applying them to cases means that one has to be aware of the values to which they give legal expression. But is also clear that philosophical theories do not tell me how rights should be interpreted in any particular case.

Consider the dignity norm in the Basic Law. One reason for it being such a successful legal concept is precisely because it means different things to different people. For a Catholic, dignity flows from man having been created in the image of God. For a Kantian, it grounds the rule that no person shall be instrumentalized by another, including by the state. A Marxist may subscribe to human dignity as a principle that forbids capitalist exploitation. Nevertheless, a legal interpretera judge-must enforce the principle of dignity as law, and not as part of religion, or of Kantian or Marxist theory. The basis of Catholic belief is partly biblical. Kant wrote more than 150 years before the Basic Law was enacted; and Marx a century before. For a judge who must interpret and apply human dignity to facts, the more important question is why and for which purpose was it transformed into a constitutional principle, after the Second World War.

Question: A jurisprudence of fundamental rights is the product of a series of formal responses to a sequence of legal disputes, not the result of thought experiments. At the same time, it is continuously evaluated in light of moral considerations. And moral considerations, in law, are deeply political.

D. Grimm: Yes, but it depends on what you understand by "political." If you want to say that there is no difference between legal and political considerations, I would disagree. If you mean that the outcome of legal disputes has political effects, or that fundamental rights do not completely determine their application to concrete cases, such that additional considerations influence the interpretation, I would not object.

Question: In the inter-war period, Hans Kelsen strongly opposed conferring, onto constitutional courts, the authority to enforce fundamental rights against statutes. He argued that doing so would establish a system of secularized natural law enforced by judges, whose task would be to "discover" the meaning of what would otherwise be vague, incomplete norms. In doing so, the judges would inevitably become supreme lawmakers. ${ }^{2}$ Of course, a version of this debate continues to this day.

D. Grimm: Kelsen had a very rudimentary notion of legal interpretation. He believed that the text of a legal norm delimits its interpretation. Within these limits the judge is free to determine the meaning. For him, there were no guiding principles, and only a relative distinction between legislation and adjudication. But given the open-endedness of fundamental rights, the limiting force of the text is so slight that, for him, the adjudication of fundamental rights could only reduce to acts of legislation. Today we have a more sophisticated understanding of legal interpretation, though we should not deny that the differences between interpreting a fundamental right and a rule of civil procedure are only one of degree.

Question: How should a court respond to a claim that a case is so politically sensitive that it is non-justiciable, placing it outside the scope of the judge's authority? In American constitutional law, there are several such doctrines: Political questions, national security exceptions, and so on. High courts in Europe, Canada, Colombia, and many other systems have rejected these doctrines as antithetical to the very idea of constitutional justice and the rule of law.

D. Grimm: This is true for Germany as well, and I agree that such doctrines are not acceptable. Constitutional law specializes on regulating politics. Consequently, the important questions to be decided by constitutional courts or apex courts with constitutional jurisdiction are per se "political" questions. If there is a norm that is applicable to such questions, then that norm must be applied, no matter how controversial the issue. Aharon Barak holds that there is no political question that should ever escape the application of the law. For him, law is everywhere, with no gaps.

${ }^{2}$ Hans Kelsen, La garantie juridictionnelle de la constitution, 44 RevUe DU DroIT PUBLIC 197 (1928). 
I may not go that far, but I share his basic orientation. If the constitution regulates the legal issue, I will apply it; if not, politicians have discretion to decide the matter. A different and delicate question is whether it might be justifiable to leave the law aside, when deciding a political question-according to the law-would endanger constitutional adjudication altogether. Fortunately, the BVerfG has never confronted such a situation.

Question: In Germany, many law professors see their role as one of helping judges construct the law, to enhance its systemic coherence, and to "teach" judges how to do their jobs better. Did moving from the academic life to the Constitutional Court change your perspective on how law professors and judges should interact?

D. Grimm: No. In contrast to the US, there is a lot of interaction between judiciary and academia in Germany. I edited a book showing this with examples of important cases. ${ }^{3}$ Academia tends to think ahead of judicial decisions, while criticizing and systematizing rulings once they have been rendered. Courts consults doctrinal commentary before deciding, and often quotes scholars in their opinions. At the BVerfG, every memo that the judge-rapporteur prepares for the deliberation of the Court contains a section on the legal literature relevant to the case at hand. This gives academia a high practical relevance, and the judiciary a broader perspective on the issue.

Question: What aspect of life on the Court did you fail to appreciate as a professor? What surprised you about life on the Court?

D. Grimm: The sheer amount of work. Of course, as a professor, I knew the statistics. The Court processed more than 4,000 cases per year when I arrived, which rose to 5,000 by the time I left. But I didn't know what these numbers really meant. When my predecessor handed the job over to me, he said, "well, I leave you with these 97 unopened cases that have been assigned to me." It was quite a shock. I asked him: "When will it be zero?" He told me: "Never, it will never get to zero." I left my successor with more than double that amount, some 200 cases.

First, intellectually, the most important work is the memo that the judge-rapporteur on a case writes, which is sometimes the length of a book. In effect, I wrote several such books anonymously! They can now be found only in the court's archives. The memo forms the basis of the deliberation, in cases with oral argument next to the pleadings. The deliberation ends with a decision; the judgerapporteur has to write the draft of the judgment; and the draft is again discussed in the full court. The deliberation on such drafts can be time-consuming, and also frustrating when colleagues try to change your text. "You should have used this word"; or "there is a comma missing"; or "the sequence of the argument needs to be changed." I considered my written German to be good, so I was not always happy to be obliged to revise a report for another deliberation.

Second, I hadn't been aware of the huge amount of trivial cases that didn't pose serious constitutional problems, but nevertheless had to be disposed of, because we did not have a certiorari procedure.

Third, on joining the Court, I was very eager to understand better what role the political affiliation of the justices played in the Court's decision-making. And I discovered that it did very little. One knows who was nominated by which political party, but that actually made little difference in the end. Legal doctrine and legal method bridge political differences in Germany, to a degree that often surprises anyone who is familiar with the U.S. Supreme Court.

Despite the workload, I loved my time on the court, especially the deliberations. Academic discussions may be more sparkling or witty, but they are also usually less reliable. As an academic, you put an opinion on the table and wait for the reaction of the scientific community. As a judge, you decide a case, which often determines the law for years to come. This makes a huge difference in your communications with your fellow judges. You can't just walk away from a discussion that you don't like. The deliberations on my Court profited from a general willingness to compromise,

\footnotetext{
${ }^{3}$ VORBEREITER-NACHBEREITER? STUDIEN ZUM VERHÄLTNIS VON VERFASSUNGSRECHTSPRECHUNG UND VERFASSUNGSRECHT SWISSENSCHAFT (Dieter Grimm ed. 2019).
} 
within limits, of course. It was quite normal for judges to change their minds upon deliberation in conference.

Question: On your Court, there has always been a mix of law professors and senior judges from the other German courts. Do you think that law professors and judges approach the underlying issues raised in important cases differently?

D. Grimm: I noticed that the dominant interest of judges was most often to ensure that the decision arrived at was correct legally, and was practical and feasible, while the professors were more interested in the ruling's consistency with past rulings, and its precedential value for the future. Will the ruling be stable, and survive as precedent? But this is a generalization. I found that the diversity of backgrounds was a big advantage for the Constitutional Court. Currently, there are perhaps too many professors. Of the sixteen justices, eight are law professors, six are judges, and two are other legal professionals.

Question: Some German constitutional scholars complain that the Court's jurisprudence has become too dense, containing too much discussion of marginal considerations. The decision are too long, cite too many cases, and ultimately do not give enough guidance to lawyers, judges, and parliamentarians. The claim is that the decisions are too often quasi-philosophical discourses that accompany a dispositive ruling, due in part to the influence of professors and their clerks.

D. Grimm: I think there is some empirical evidence for this view. The opinions become longer and longer, sound more academic, and contain a growing number of quotations and citations. It may have something to do with the clerks who want to make their memos watertight. But the judges decide what parts of the prepared material appear in the opinion. The growing number of professors also plays a role. But I defend the practice of the Court to carefully develop and explain the principles and standards on which they decide the case at hand (usually part C.I. of the opinion). What I cannot confirm is that rulings give insufficient guidance to the judges below, parliament, or the ministries, compared with earlier periods.

Question: What is your view on precedent? After all, German and European constitutional law is today constructed on a case-by-case basis, through precedent.

D. Grimm: Civil law systems that are based on codified law instead of precedents don't have the stare decisis-rule. Therefore, precedents have no binding effect. Courts may deviate from prior decisions at any time. But this does not mean that precedents are unimportant. This is particularly true for constitutional law, which is less comprehensive, less coherent and less systematic compared to the private law codes. The BVerfG does not deviate from precedent easily. To the contrary, it draws the legitimacy of its rulings partly from the fact that they are part of a longstanding, established jurisprudence. This is one reason for the often long chains of citations. It even happens that a deviation is not openly admitted, so that only experts will recognize a subtle change. One has an easy job, as the judge-rapporteur, if one proposes to continue on the line that was established forty years ago. One has a difficult job if one wants to convince colleagues that a precedent may have been correct twenty years ago, but now should be abandoned.

I experienced this problem when I tried to change the status of one of the BVerfG's most famous cases - the Elfes case 4 —decided in 1956, before Lüth. Elfes held that Article 2(1) — the free development of one's personality-is a catch-all right: any human activity not expressly protected in the Basic Law is presumed to be covered by Article 2(1). This meant that it not only protected what deserved protection-either because of its importance for the free development of one's personality, or for its vulnerability to incursions through government measures-but also behavior that we regard as harmful in every society, like fraud or murder. The limitation clause, of course, permits prohibiting and punishing harmful acts, but they still fall within the scope of the right. My view had long been that the wide scope given to this liberty norm was not defensible, either historically or functionally; and that only liberties of a similar importance as those enumerated in the

${ }^{4}$ Bundesverfassungsgericht [BVerfG] [Federal Constitutional Court] BVERFGE 6, 32, 1 BvR 253/56, (Elfes, Jan. 16, 1957). 
Basic Law deserved to be protected. But Elfes had enormous appeal because it seemed to close all the gaps in the bill of rights.

As a justice, I waited for an appropriate case to overrule Elfes; and in my second year on the bench one arrived. It concerned a statute that confined horse riding in the forests to paths reserved for that purpose. ${ }^{5}$ The horse lovers brought an individual complaint, claiming that the law was unconstitutional because it violated their liberty under Article 2(1). The case was trivial, and we easily found the statute proportional on the merits - so it was perfect for trying to convince the Court that we should end this trivialization of fundamental rights. But I lost 7-1. I am pretty sure that I would have had a chance to win had I been on the Court in 1957. But, by now, Elfes was a 32 years old precedent, and had been routinely and constantly applied. I wrote a dissenting opinion, which every German law student knows. The dissent also triggered an academic debate about the nature of Article 2(1), with only a minority being on the side of my proposal to narrow its scope, and to give a more emphatic understanding of rights that are truly fundamental. I should add, however, that Article 2(1) has the advantage of being adaptable to new circumstances. Over time, the Court has recognized a number of specific rights that are responsive to new threats to free personal development, such as the right to protection of personal data. Of course, I support these concretizations of Article 2(1).

Question: What are your views on dissenting opinions? Did members of your Court believe it to be a professional obligation, or informal norm, to work to achieve as much consensus as far as possible?

D. Grimm: Dissenting opinions are not in the German tradition, but were nonetheless introduced in 1970, yet only for the Constitutional Court. I was in favor of the reform, but I wrote only two dissenting opinions during my entire tenure. I made it a rule for myself that I would dissent only if the issue was truly of fundamental importance to me. My predecessor, the famous jurist Konrad Hesse (1919-2005), made it a principle never to write a dissenting opinion himself. A great dissenter on the BVerfG may write, at most, twelve or fifteen dissenting opinions in twelve years. The tradition according to which the Court speaks with one voice is still very much alive. But on the other hand, nobody is afraid of dissenting. Threatening to file a dissenting opinion if the Court is not willing to follow you does not impress anyone.

Question: Does seeking to avoid dissenting opinions_compromise-reduce the clarity of the decision?

D. Grimm: As I said, the Court is not afraid of dissenting opinions. Rather, they cultivate a spirit that facilitates consensus. Sometimes compromises are reached at the costs of clarity, but not necessarily so. If the controversy was just about wording, one of the presidents of the Court used to suggest, we should ask: "Do we need this sentence at all?"

Question: Is there concern that different views on the Court could be viewed as political disagreements?

D. Grimm: In the debate about the permission of dissenting opinions one argument was that disclosing the differences within the Court would hurt its authority. The judges in my time did not share this concern. Usually the Senates do not disclose the result of the vote. But there are many exceptions. Sometimes, judges want to tell a divided society that they were divided as well; sometimes they want to demonstrate to a divided society that they could be unanimous. I asked myself often whether the public views controversies within the Court as political disagreements. This is certainly the case when the division among the judges follows party lines. But these cases are very rare. What can be observed, however, is that the losers will seek to diminish the value of a judgment when it is not unanimous.

\footnotetext{
${ }^{5}$ Bundesverfassungsgericht [BVerfG] [Federal Constitutional Court], BVERFGE 80, 137, 1 BvR 921/85, (Riding in the Forest, Jun.6, 1989) (Grimm, D. dissenting) at 164.
} 


\section{The Constitutional Court and Inter-Judicial Relations}

Question: We are interested in your views on institutional aspects of constitutional justice. Since Lüth, for example, the BVerfG has supervised how the civil courts have resolved tensions between fundamental rights, as well between rights and provisions of the civil code. These cases raise delicate issues of balancing; but they also involve subtle exercises in diplomacy, precisely because the civil courts possess their own autonomous authority to interpret and apply the codes. The Lüth ruling, after all, insisted that the Federal Court of Justice [Bundesgerichtshof, BGH] proceed somewhat like a constitutional court in such cases, in that they are expected to engage in proportionality-based balancing within guidelines laid down by the Federal Constitutional Court. ${ }^{6}$

D. Grimm: Due to the division of labor within the First Senate of the Court, I was the judge-rapporteur on cases involving freedom of speech and the media, freedom of assembly and association, and personality rights like privacy, cases that often involved cases that originated in private law litigation. The BGH was not so much expected to act like a constitutional court in such cases, but only to ensure that, if a decision would have a limiting effect on a fundamental right, it interpreted private law "in the light" of that right. But it's true that the Lüth ruling revolutionized the relationship between private law and constitutional law, and consequently also the relationship between civil courts and the constitutional court.

Until Lüth, private law had to be compatible with the constitution, and the constitutional court was authorized to review private law provisions as to their constitutionality. But once determined to be constitutional, the influence of constitutional law ended. Their interpretation and application was exclusively a matter of private law, and therefore the business of the civil courts. Lüth changed this. It developed the (indirect) horizontal effect of fundamental rights. On the one hand, this meant that fundamental rights continued to bind the state-including the civil courts - but they did not bind private persons in a direct sense. On the other hand, it meant that private law's application came under the influence of constitutional law, and under the control of the constitutional court. This is what the term "constitutionalization of private law" (and, as a matter of fact, of all ordinary law) means.

Question: One can see why the BGH, and the other federal apex courts, might become jealous of their authority, given the Constitutional Court's determined effort to "constitutionalize the private law."

D. Grimm: By all means. In the early years of the Constitutional Court, tensions with the BGH occurred more than once. The civil courts had older traditions. Civil law and civil judges enjoyed the highest reputation. Students learned the history and the foundations of civil law, before they were acquainted with any other law. There was a saying: "the constitutional court is full of layjudges, not 'real' judges who know the subtleties of such fields like contracts and torts, corporate law, taxation." Today, all this has changed. There may be a conflict with the BGH, or another supreme court from time to time, but the hierarchical supremacy of the BVerfG is now accepted. It certainly helps that most law clerks on the Constitutional Court are judges in the other systems. They usually come to the BVerfG for two or three years, and then return to the ordinary courts. Currently the presidents of all five Supreme Courts were former law clerks of the BVerfG. However, cases can generate conflict from time to time, because when the private law is placed under the influence of constitutional rights, there is no longer a clear borderline between the two.

Question: The German Court has been at the center of a long series of high profile confrontations with the European courts, most of which have been resolved to the benefit of all sides, and in ways that have elevated the status of fundamental rights as higher law. Today, it is clear that national constitutional courts, the Court of Justice of the European Union, and the European Court of Human Rights, will undermine their own effectiveness if they fail to accommodate

\footnotetext{
${ }^{6}$ The classic study in English is Peter Quint, Free Speech and Private Law in German Constitutional Theory, 48 MD. L. REV., 247 (1989).
} 
one another, wherever possible. Yet, how they should interact remains unclear in important respects.

D. Grimm: We have to distinguish between the two European courts. The European Court of Human Rights doesn't have a mission of unifying the law; its task is to guarantee a minimum standard of fundamental rights protection in the 47 member states of the Council of Europe. So, this relationship is easier. If a German ruling is found to have violated the Convention, German courts, including the BVerfG, will seek to adjust their jurisprudence to the Strasbourg court's views, within limits. As you know well, we cannot accept an interpretation of the Convention that is openly unconstitutional under the Basic Law. So far, we have been able to live with this.

For its part, the CJEU has asserted the power to declare inapplicable national legal norms that conflict with EU law. Germany accepts the authority of European law, but only to the extent that EU norms are not ultra vires, and do not conflict with the fundamental values of the German Constitution, whereas the CJEU does not accept any exception from the primacy of EU law. In disputes about the question whether the EU acted ultra vires, the CJEU claims the final word. In contrast, the BVerfG claims this same power for itself, as far as the applicability of EU law in Germany is concerned. Behind this controversy lie different assumptions about the source of EU law. According to the German Court, EU law owes its applicability within Germany to decisions of the German Parliament, hence only to the extent that the Bundestag has expressly authorized the transfer of specific powers to the EU. The European Court of Justice starts from the premise that European law has dissolved its bonds with member states, such that the EU is now an autonomous source of its own law.

These premises are irreconcilable. I don't see a resolution to this problem, because neither court will compromise. We don't have a closed hierarchy of laws in Europe, as we do in a state. As a consequence, it may happen that two contradicting judgments, in one and the same case, exist at the same time without an ultimate legal authority to decide which court is right. This means that there is only a political solution. For jurists, it is difficult to live with such a situation. But some people also see the positives, in that it forces a dialogue in which both courts take each other's positions into account.

Question: We return to the issue of inter-judicial dialogue. In this case, there is growing interest for each high court in Europe to show that it seeks to understand and accommodate the perspectives of external high courts, whether domestic or European.

D. Grimm: Dialogue of courts is of course a metaphor, as there is no real dialogue, and certainly no dialogue before a case is decided. If a national constitutional court finds that an EU law or legal act is ultra vires, it refers the question to the CJEU and explains its concerns; the Luxemburg Court then deals with these questions - a process that we may call "dialogue." Or it chooses not to deal with the problem, and simply rejects the claim.

Question: With respect, it would seem that dialogue is not just a metaphor, when the two courts decide a series of related cases and, as a result, come to appreciate one another's respective positions. In any event, the Strasbourg Court's reliance on the norms and principles of "dialogue" is now official policy. ${ }^{7}$ Within Germany, the BVerfG has engaged in continuous dialogue with the $\mathrm{BGH}$ on how to apply speech rights in the private law, since $L \ddot{u} t h$, with impressive results.

D. Grimm: I agree that there is a number of cases where national and European courts modified their original position because of the concerns of the other side, and I welcome that. It should happen in a climate of mutual respect, especially since the European courts are not in a hierarchical position. They are not appellate courts. They cannot reverse the judgments of the national courts. To the contrary, the BVerfG speaks from a hierarchical position when it reviews a judgment of the BGH. Nobody doubts that. This should not prevent the BVerfG from taking

\footnotetext{
${ }^{7}$ Dialogue among European judges is the "bedrock of the Convention system," declared the President of the Strasbourg Court in 2020; 2020 ANN. ReP. EUR. CT. H. R. (European Court of Human Rights) 133, https://echr.coe.int/Documents/ Annual_report_2020_ENG.pdf. See also the website: European Court of Human Rights, SUPERIOR COURTS NETWORK, https://www.echr.coe.int/Pages/home.aspx?p=court/dialoguecourts/network\&c=.
} 
the arguments of the BGH (and other German courts) seriously; but even when it does not do so, the BGH is not entitled to disregard the Constitutional Court. The German courts, however, can refuse to implement a judgment of the European courts.

Question: In Europe today, inter-judicial dialogues involving the adjudication of fundamental rights can be extraordinary complex, especially when they involve more than two courts. Perhaps the most prominent examples have involved the domestic constitutional courts, the domestic supreme civil court, and a European court. You were judge-rapporteur for the Von Hannover ruling of the BVerfG, that eventually was evaluated by the Strasbourg Court in Von Hannover $I .{ }^{8}$ This case was quite sensitive because it involved balancing between freedom of press and privacy rights within the private law, under the Lüth precedent and the proportionality principle. Simplifying, since Lüth, the BVerfG and the BGH had, over many decades, reached a general understanding on authority was to be divided in this area, mutual respect that was reflected in the BVerfG's ruling (1999). One might even call that outcome a product of inter-judicial dialogue and diplomacy. But the European Court of Human Rights, in effect, balanced behind the BVerfG's back [Von Hannover I, 2004]. In the end, an accommodation was reached, as each court compromised [Von Hannover II, 2012]. ${ }^{9}$

D. Grimm: Let me first address the underlying problem from my perspective. Article 53 of the European Convention on Human Rights (ECHR) prohibits interpretations of the Convention that would lower the national standard of fundamental rights protection. This is easy if we are in the realm of public law with its asymmetrical constellation: the individual has entitlements against the state, in the form of rights; the state is bound by these rights. But over time, an increasing number of cases arrived in Strasbourg that had begun as private law litigation. And here we have a symmetrical constellation: both parties have pleaded fundamental rights, which the courts must accommodate. If, in this type of cases, the balance struck by the national court is reversed by the European Court of Human Rights (ECtHR), it inevitably lowers the protection of the fundamental right that had prevailed at the national level. Von Hannover was such a case. In the BGH and the BVerfG, freedom of the press had prevailed over privacy, given the facts of the case. The European Court required the opposite. So the question: is this outcome compatible with Article 53 ECHR?

Question: Proponents of overlapping systems of rights protection argue that the deliberative process will typically improve when multiple courts participate in it. Sabino Cassese has strongly argued this point in this volume. Do you think that the German approach to how judges ought to balance privacy rights with those of the press has been improved as a result of Van Hannover saga, or is the settlement between the German courts and the European Court of Human Rights mostly cosmetic? Looking back, did "going to Strasbourg" add anything of value to the German approach to balancing privacy and freedom of the press? Can such "irritants" or "disruptions" lead to doctrinal improvement?

D. Grimm: Over time, I have come to recognize that the back-and-forth between the German and European courts was useful in this case, and that disruptions like this can be useful more generally. The Caroline of Monaco cases sharpened the underlying issues, and made us rethink what we had before taken for granted. And the changes made were not merely cosmetic, but an improvement. The Strasbourg Court asked us to give more weight to privacy, and to reconsider our attachment to ideas and factors that were not always clear or compelling, such as the difference between a "public figure" and a "public figure par excellence." On the other hand, the ECtHR had to reconsider its paternalistic view of the function of media.

Question: Partly as a result of the Von Hannover conflict, the Strasbourg Court now accepts a rule of diplomacy: that it will give presumptive deference to a domestic constitutional court that

\footnotetext{
${ }^{8}$ Bundesverfassungsgericht [BVerfG] [Federal Constitutional Court] BVERFGE 101, 361, 1 BvR 653/96 (Caroline von Monaco II, 1999).

${ }^{9}$ Von Hannover v. Germany (No. 1), 59320/00 Eur. Ct. H.R. (2004); Von Hannover v. Germany (No. 2),. 40660/08 Eur. Ct. H.R.and 60641/08 Eur. Ct. H.R. (2012).
} 
has shown itself to have balanced in good faith, in light of the principles developed in the European Court's case law.

D. Grimm: It was not always so, and certainly not in the first Von Hannover decision of 2004. But what you describe is in my view an adequate way to deal with the problem. It corresponds with the "margin of appreciation" that the ECtHR concedes to the member states. The conflict between media freedom and privacy is solved in very different ways in, say, France, Germany and the UK, and these solutions are deeply rooted in the national legal culture of each state. There is no need to impose one alternative on all forty-seven member states. I think that Strasbourg Court should be aware that recognition of legitimate diversity is a condition for the acceptance of its jurisprudence in the member states.

Question: The "settlement" achieved appears to resemble the equilibrium reached by the BVerfG and the BGH, in similar cases involving speech and the press. It would seem that the structure of these two "dialogues" are quite similar, leading to similar results. Both rest on what we might call a "diplomatic" settlement between two courts, based on a "mutual recognition" of each other's respective competences. ${ }^{10}$

D. Grimm: I agree. But the great difference is that the German Constitutional Court's position vis $a$ vis that of the BGH is one of clear hierarchical superiority. It is the Constitutional Court's duty to correct the Supreme Court when it has not recognized that a right is in play, or if it has engaged in faulty balancing, due to giving too little weight to one of the values or interests in tension. I do not agree that the Strasbourg Court has a similar duty to correct how a national high court balances in cases wherein two rights conflict.

\section{The Court and Parliament}

Question: In Germany, the metaphor of "constitutional dialogue" has long been used to describe the BVerfG's interactions with the German Parliament, in cases involving fundamental rights. These dialogues are organized by the proportionality principle, and by the development of creative remedies whose purpose is to maintain a space for legislative decision-making, within guidelines stipulated by the Court.

D. Grimm: Creative remedies have indeed been developed. The statute on the Constitutional Court stipulates that a law can be constitutional or unconstitutional, and nothing in between and that, if unconstitutional, it must be declared null and void. However the Court has developed degrees of unconstitutionality in order to give Parliament a voice in how to deal with a law that violates the constitution. ${ }^{11}$

Question: The academic literature is split. Some claim that these techniques are too intrusive, functioning to tighten the control of the Court over Parliament. Others claim that they compromise constitutional control, risking the Court's effectiveness.

D. Grimm: I don't share either criticism, because I think they respect rather than restrict parliament. I myself, however, am critical of declaring a law unconstitutional while stating precisely what a constitutional law should look like. Dictating outcomes is not the Court's business. But the argument on the other side is that doing so saves time, and saves the legislature from

\footnotetext{
${ }^{10}$ Alec Stone Sweet \& Clare Ryan, A Cosmopolitan Legal Order: Kant, Constitutional Justice, and the European Convention of Human Rights, 196-201, 230-232 (2018).

${ }^{11}$ Among other constitutional remedies, Justice Grimm notes the following. The Court may declare a law unconstitutional, while remaining applicable for a limited period of time, when annulment would create greater harm than tolerating it temporarily. It may declare a law null and void (ex nunc, not extunc), as when the Court overrules a precedent on which the legislature had relied. Another possibility is for the Court to declare a law unconstitutional and no longer applicable, but not null and void, to give Parliament opportunity to correct the fault, when there exist multiple solutions for doing so. The Court may also issue warnings to Parliament, as when the constitutionality of the law is uncertain, and depends on future developments; in such cases, the BVerfG may place the legislature under a duty to supervise how the law is enforced. Finally, there are judgments that lay down binding interpretations of the law in order to render it constitutional ["saving constructions" in American parlance].
} 
making a new mistake. Usually the legislature just follows the Court, which can lead to judgemade law when the Court's guidelines are too detailed. But this is how Parliament uses our decisions, not what the Court requires.

Question: Aharon Barak suggests that, with respect to rights review, that a basic function of a constitutional court is to delineate a "zone of proportionality," within which the legislator is free to make law. ${ }^{12}$ If so, then enforcement of the proportionality principle is a dialogic technique, at least in the hands of a skilled judge.

D. Grimm: Yes, one may put it that way. I myself would prefer to describe the court's task as telling the legislature whether the impugned law is proportionate or not, and why. For determining the "zone of proportionality," the court might not have the necessary information or the capacity to anticipate all possible scenarios.

Question: In the balancing in the strict sense stage, it may at times be difficult to maintain an extensive zone of proportionality, insofar as a ruling may have excluded certain options, and established specific guidelines for "correcting" the law. The Court may have, effectively, dictated certain kinds of choices.

D. Grimm: In my time on the Court, there were not many cases where the application of the proportionality principle left the legislature with just one single alternative. On the other hand, I remember a case, in which I was judge-rapporteur, where the legislature argued that the solution it had chosen was the only possible one. ${ }^{13}$ So we felt obliged to explain in detail what a proportional alternative might look like, without stipulating that this was the only available alternative. The legislature adopted our suggestion.

\section{E. Challenges, Past and Future}

Question: We are interested in your views on current legal issues in Germany and beyond. First, if you had the power to do so, how would you amend the German Basic Law?

D. Grimm: You know that the German Constitution has been amended frequently. In the seventy years of its existence, we have had almost seventy amendments, many of them concerning more than one article. Not all of them have improved the Basic Law, but they have made it longer. The amended provision on the right to asylum, for example, is forty times longer than the original. The article now reads more like detailed administrative instructions than a fundamental rights text, a result of compromises between the political parties. I would turn the clock back in this respect. All we need is the fundamental right, a limitation clause where necessary, and the enforcement of the proportionality principle by the Court. I have therefore long advocated changing the amendment clause. Our amendment procedure is too easy. It uses the same procedure as for ordinary legislation, activated by the same actors who normally legislate. The only difference is the supermajority requirement. The procedure should reflect more clearly the difference between statutory lawmaking and revising the constitutional rules of the game.

Question: Do you think Article 79(3) of the Basic Law_-the so-called eternity clause-should be reconsidered?

D. Grimm: No, I would not change that clause. Given Germany's history, we need something like it.

Question: You have argued elsewhere about the importance of constitutional entrenchment. And, when you look around the world, you see the problems that can result when parliamentarians themselves control the process, as in Poland and Hungary. A two-thirds [vote of parliament]

\footnotetext{
${ }^{12}$ Aharon Barak, Proportionality: Constitutional Rights and Their Limitations, ch. 14 (2012); Alec Stone Sweet \& Jud Mathews, Proportionality Balancing and Constitutional Governance: A Comparative and Global Approach, ch. 5 (2019).

${ }^{13}$ Bundesverfassungsgericht [BVerfG] [Federal Constitutional Court] BVERFGE 90, 60 (Fees for Public Television, Feb. 22, 1994).
} 
decision rule governing constitutional amendment can be used to weaken rights protection and constitutional courts.

D. Grimm: It is very difficult to blame the voters for giving a two-thirds majority to a party.

Question: In Hungary, a bare majority of the vote translated into two-thirds of the seats.

D. Grimm: In such a situation, if a populist movement gets a two-thirds majority, in a more or less free election, then everything is lost. In Poland some $37 \%$ of the electoral votes translated into an absolute, but not a two-thirds majority. So the populist party had to resort to violating the constitution to achieve its goal of systemic transformation. Under these circumstance, it depends on the support of the people for the constitution. In Poland, it was not high enough.

There is not much we can do about these threats. At the same time, the Hungarian and the Polish examples show the importance of the electoral system. The consequence that I would draw for Germany from these experiences is that we should entrench the electoral system on constitutional level. At present, it is regulated on statutory level.

Question: The German parliament is not only one of the most effective parliaments in the world, it also takes very seriously its responsibilities to respect rights and secure the rule of law. This gives a huge advantage to the Constitutional Court: the Court can presume its own institutional effectiveness, before the dialogue even begins. Do you have any advice for judges on other constitutional courts who are not in that kind of position, but face parliaments that are hostile or indifferent to judicial review?

D. Grimm: Germany is indeed in a lucky situation. The Basic Law and the Constitutional Court developed their strength under particularly favorable conditions. The comparative perspective helps to perceive the importance of context. Of course, a wise handling of the court's power can reduce the potential for conflict, but this alone is not enough if the environment is unfavorable to judicial review.

Question: To what extent is the potential for political backlash related to the judicial methodology a court adopts? Some would argue that adopting proportionality, which is a relatively aggressive and intrusive standard of review, is a provocative move, likely to generate conflict with the legislature. Some judges in America advocate so-called "originalist" positions, in part, for prudential reasons.

Dieter: It is of crucial importance, for the acceptance of judicial review, that a constitutional court takes decisions that plausibly follow from the general provisions of the constitution, rather than seeming to be a products of the judges' political preferences. However, because the general public does not read opinions but obtains its information through media reporting, how the media cover the court is also crucial. Regarding the role of proportionality in this context, I think that the BVerfG would never have reached the effectiveness and recognition that it enjoys without having relied upon it. The proportionality principle today carries the main burden of fundamental rights protection. But I think that it can be applied in an aggressive or a restrained way. The second way is certainly recommendable, as well in the interest of the democratic mandate of the legislature as in the Court's institutional self-interest. Originalism is of no importance to the BVerfG, and rightly so. It is not necessary for making prudent use of judicial review powers.

Question: From an American perspective, one could argue that the German and European courts are originalist courts. Why? Because the founders qualified fundamental rights through limitation clauses, and delegated constitutional judges the authority to "complete" these incomplete provisions over time, through their rulings. How most powerful European constitutional courts adjudicate rights is precisely what the founders wanted, and expected them to do, by design.

Dieter: Wonderful! I see what you mean. It is a different understanding of "originalism," not that courts should interpret the words of the constitution in the way they were understood when the constitution was drafted, or how they were intended by the framers. Rather the courts are to fulfil the function which the founders had designated for them. In the US, it is uncertain whether the original constitution included judicial review. In Germany and many other countries, there cannot be any doubt about that. However, this does not mean that they foresaw and wanted 
everything that courts decide later on. Do you think that they imagined or expected that the BVerfG would tell the legislature what to do, and how to do it? If this was what the framers wanted, why did it take the Court 25 years to develop these practices? I think that the German Court was on solid ground when it developed the "legislative duty to protect" [the Abortion I case of $1975^{14}$ ]. But my guess is that in 1949 there would have been little support for a court that would force the legislature to make a law that is does not wish to make.

Question: Do Articles 1-20 of the Basic Law- or fundamental rights, more generally - give too much "inherent" power to the constitutional judge? Do these provisions lay down a positive duty, binding on all state officials, to create the conditions under which rights can be enjoyed?

Dieter: This is the result of interpretation. The tremendous importance that fundamental rights gained over time - through the BVerfG's case law - was not foreseeable by the founders, but it is in the consequence of their intention to strengthen fundamental rights.

Questions: The development of the European courts, too, pose challenges to constitutional law. There is now a widespread sensitivity to what is sometimes called "national constitutional identity." The notion is today a legal construct, that gives a structure to inter-court dialogue, both cooperative or conflictual. The BVerfG, of course, has been at the forefront of these developments, from the Solange cases, ${ }^{15}$ to Görgülü ${ }^{16}$ to the recent decision on the European Central Bank. Earlier, you stated that the ultimate issue is whether and when the BVerfG actually uses its powers to declare an EU act ultra vires. The issue has now been engaged, in the BVerfG's ruling on the $\mathrm{ECB}$, of May 2020.

Dieter: I expected it to happen at some point. Whether the PSPP case ${ }^{17}$ on the Bank was the best occasion is a different question. The Danish Supreme Court and Czech Constitutional Court did it earlier, but only the German Court's refusal to follow the CJEU drew wide attention. It is a mistake to judge the ultra vires jurisprudence only from the viewpoint of the efficacy and unity of EU law. By definition, every European ultra vires act withdraws a subject matter from the domestic political process without authorization, thus limiting the range of the national constitution. The CJEU does not understand itself as protector of national democracy. It is also obvious that the Commission and the Council, too, can be the source of ultra vires acts, not just the CJEU. But the CJEU is extremely reluctant to declare European legal acts as ultra vires. consequently, the only safeguards of national democracy are the constitutional or highest courts of the member states.

Question: Looking forward, in the EU, national constitutional courts are now using the preliminary reference procedure more often. And in the ECHR, Protocol no. 16 now permits advisory opinions. Might these procedures help to structure more constructive dialogue among courts?

D. Grimm: That is indeed my hope.

\footnotetext{
${ }^{14}$ Bundesverfassungsgericht [BVerfG] [Federal Constitutional Court], BVERFGE 39, 1 (Abortion 1, Feb.25, 1975).

${ }^{15}$ Bundesverfassungsgericht [BVerfG] [Federal Constitutional Court], BVerfGE 34, 269 (Soraya, 1994); Bundesverfassungsgericht [BVerfG] [Federal Constitutional Court] 73, 339, 2 BvR 197/83 (Solange II, 1987). See JulIANE Koкотt, Report on Germany, The European Court and National Courts Doctrine \& Jurisprudence: Legal Change in Its Social Context, ch. 3 (in A-M Slaughter, A. Stone Sweet, \& J. Weiler eds.,1998).

${ }^{16}$ Bundesverfassungsgericht [BVerfG] [Federal Constitutional Court] BVerfGE 111, 307 (Oct. 14, 2004). Frank Hoffmeister, Germany: Status of European Convention on Human Rights in Domestic Law, 4 INT'L J. OF ConsT. L., 722 (2006).

${ }^{17}$ Bundesverfassungsgericht [BVerfG] [Federal Constitutional Court] Case 2 BvR 859/15 (Public Sector Asset Purchase Program, 2020). Isabel Feichtner, The German Constitutional Court's PSPP Judgment: Impediment and Impetus for the Democratization of Europe, 21 GERMAN L.J. 1090 (2020).
}

Cite this article: Stone Sweet A, della Cananea G (2021). A Conversation with Dieter Grimm. German Law Journal 22, 1541-1554. https://doi.org/10.1017/glj.2021.91 